\title{
Study on the Extension of Shelf-life by Activation of Inherent Lactoperoxidase System in Raw Cow Milk
}

\author{
PRASHANTA POKHREL ${ }^{1,2^{*}}$ and SUMAN KUMAR LAL DAS ${ }^{1}$ \\ ${ }^{1}$ Central Campus of Technology, Tribhuvan University, Dharan, Nepal \\ ${ }^{1}$ Department of Food Technology \& Quality Control, Kathmandu, Nepal
}

Effectiveness of lactoperoxidase in raw cow milk was studied to observe the increase in shelf-life. Lactoperoxidase system was activated within two hours after milking by the addition of hydrogen peroxide and potassium thiocyanate, then milk was kept at different conditions viz. refrigerated condition $(5 \pm 2)^{\circ} \mathrm{C}$, room temperature $(25 \pm 3)^{\circ} \mathrm{C}$ and at $(35 \pm 2)^{\circ} \mathrm{C}$. The keeping quality of raw milk was determined by the acidity, which when reached $0.18 \%$ as lactic acid, was considered spoiled.Results indicated that the lactoperoxidase system (LP-s) increased the shelf-life of raw cow milk kept at room temperature $(25 \pm 3)^{\circ} \mathrm{C}$ and refrigeration temperature $(5 \pm 2)^{\circ} \mathrm{C}$ significantly $(p<0.05)$; however no significant increase in shelf-life was observed between the control and $L P-s$ treated raw milk sample held at $(35 \pm 2)^{\circ} \mathrm{C}$.

Keywords: Acidity, Cow milk, Keeping quality, Lactoperoxidase, Shelf-life.

\section{Introduction}

The annual production of milk in Nepal is about $1.35 \mathrm{MT}$ per year (CBS, 2008). In developing countries, milk after collection is mostly transported to processing plants by unrefrigerated trucks. Higher temperature directly affects the shelf-life and safety of milk (Mariba, 2006). In geographically and climatically diversified country like Nepal, the milk produced by farmers cannot be kept for more than 4-5 hrs at ambient temperature after milking. Milk preservation prior to distribution and sale is major problem in Nepal. On transporting the collected milk up to processing plant, it gets spoiled (Acharya, 2010). In this context, use of the lactoperoxidase system (LP-s) in areas which currently lack an adequate infrastructure for collection of liquid milk, would ensure the production of milk as a safe and wholesome food, which otherwise would be virtually impossible (CAC, 1991b). The cost of activation of LP-s is US\$ $0.0025-0.01$ per liter of milk. It's economically viability, either as a standalone system or in combination with refrigeration, and it's potential to significantly reduce milk losses and thereby increase the amount of milk collected leads to direct benefits for both milk producers and consumers (FAO/WHO, 2005).

Milk peroxide, lactoperoxidase is an enzyme, which is naturally present in fresh raw bovine milk. It can oxidize thiocyanate ions in the presence of hydrogen peroxide. By this reaction, thiocyanate is converted into hypothiocyanous acid (HOSCN). At the $\mathrm{pH}$ of milk HOSCN is dissociated and exists mainly in the form of hypothiocyanate ions (OSCN-). This agent reacts specifically with free sulphydryl groups, thereby inactivating several vital metabolic bacterial enzymes, consequently blocking their metabolism and ability to multiply. In freshly drawn milk, the antimicrobial activity is quite weak and lasts for up to two hours because the milk contains only suboptimal levels of the thiocyanate ion and hydrogen peroxide (CAC, 1991b).

\footnotetext{
*Corresponding author, E-mail: prashanta.pokhrel@gmail.com
}

The LP-s is considered as one of the body's natural defence mechanisms against microbial infections. Gram negative, catalase positive organisms are more readily inhibited by LP-system than are gram positive, catalase negative bacteria. Gram negative, catalase positive organisms (Coliforms, Salmonella, etc) are not only inhibited, but are killed if sufficient hydrogen peroxide is provided. On the other hand the action of LP system against gram positive organisms is generally bacteriostatic and not lethal (FAO/WHO, 2005; CAC, 1991b).

\section{Materials and Methods}

Materials- In total, 9 raw cow milk samples were collected just after milking from farmers of Dharan municipality-14. Sodium percarbonate (source of hydrogen peroxide) and potassium thiocyanate were available at Central Campus of Technology.

Activation of lactoperoxidase system- Thiocyanate content of milk was determined according to the method given by (CAC, 1991b). The activation of Lactoperoxidase system was done within 2 hrs of milking as the method given by FAO/WHO, (2005). LP-s was not activated in control samples.

Physicochemical and Microbiological analysis- Acidity, protein content, fat $\%$, solid not fat (SNF) content, lactose content, ash content, clot on boiling test (COB) and the microbiological tests; total plate count (TPC) and coliform count were determined according to the method given by NDDB, (2001).

Determination of keeping quality (KQ)- The keeping quality of milk was accessed by measuring the acidity of milk. When the acidity of milk reached 0.18 per cent as lactic acid, the milk was considered as spoiled. The control sample and LP activated raw milk samples were stored at 3 different conditions; refrigerated $(5 \pm 2)^{\circ} \mathrm{C}$, room temperature $(25 \pm 3)^{\circ} \mathrm{C}$, and at $(35 \pm 2)^{\circ} \mathrm{C}$. KQ and microbiological analyses was carried out every hour in case of $35^{\circ} \mathrm{C}$ while at room temperature done at every 3 hours and in case of refrigerated temperature they were carried out daily until the milk was spoiled. The 
experiments were repeated nine times (each in triplicate).

Statistical Analysis- Data on physicochemical and microbiological analyses were tabulated for comparison and were graphically represented using Microsoft ${ }^{\circledR}$ Excel-2002. Data were statistically processed by GenStat Discovery $2^{\text {nd }}$ edition version 7.22DE for Analysis of Variance. Mean of the data were separated whether they were significant or not by using LSD (least square difference) method at $5 \%$ level of significance $(\mathrm{p}<0.05)$.

\section{Results and Discussion}

Physicochemical properties of raw milk- The specific gravity, fat, solid not fat (SNF), protein, lactose, ash, acidity and water content of normal milk were found to be $1.0275 \pm 0.001$, $3.8 \pm 0.08,8.35 \pm 0.34,3.38 \pm 0.14,4.29 \pm 0.6,0.64 \pm 0.04,0.13 \pm 0$, $87.75 \pm 0.42$ respectively. The values of physicochemical properties of the raw milk samples were within the range given by authors (Eckles et al., 1973; Bylund, 1995; 2006; De, 2008). According to De, (2008) the composition of milk depends upon the species, breed, season, feed \& water, stage of lactation, age, time of milking, weather etc.

Initial Microbial count of milk (log $c f u / m l)(n=9)-$ Analysis of the raw milk showed that the milk was contaminated with Coliform. The TPC and Coliform count were found to be $5.4 \pm 3.05,4.17 \pm 2.1 \log \mathrm{cfu} / \mathrm{ml}$ respectively. The TPC in the normal sample is greater than the European Union standard. EU standard for TPC in raw milk is $<5 \mathrm{log} \mathrm{cfu} / \mathrm{ml}$ (Younan, 2010). According to De, (2008) the grade of the raw cow milk is good. Eckles et al., (1973) stated that, when milk leaves the udder of a normal cow, the total number of bacteria is not very great. It varies considerably, but 500 to 1000 per milliliter may be a fair estimate. High microbial load in normal milk showed the contamination of milk. Likewise high load of coliform indicates contamination from manure or soil. Other possible causes of contamination are the hands and arms of the milking person, water and the milking environment. (Frazier and Westhoff, 1995). According to FAO/WHO (2005), the hygiene of milk plays an important role in extending the shelf-life by lactoperoxidase system.

Thiocyanate content of raw milk and activation of lactoperoxidase system- The thiocyanate content of milk sample ranged from 2.8 to 3.2 with an average of $3 \mathrm{mg} / \mathrm{L}$. Lower values of thiocyanate are due to the low amount of cyanoglucosides present in the feed. Fernández et al., (2005) obtained an average of $2.32 \mathrm{mg} / \mathrm{L}$ thiocyanate content on individual cows. The thiocyanate level determined was lesser in comparision to the range given by CAC, (1991 b), which has stated that the thiocyanate content in bovine milk ranges from 4 to $5 \mathrm{mg} / \mathrm{l}$ in general. Thiocyanate content in milk depends upon the cyanoglucosides present in the feed (Walstra et al., 2006).

Acid development in milk- The acidity of control milk sample increased with time from the very beginning in the control samples kept at $35 \pm 2^{\circ} \mathrm{C}$ and $25 \pm 3^{\circ} \mathrm{C}$ (Figure land 2), while the acidity of LP-s treated sample remained unchanged up to the 2 and 3 hours after LP-s activation, then it increased. Likewise at refrigeration $\left(5 \pm 2^{\circ} \mathrm{C}\right)$, the acidity remained unchanged up to 1 day and 3 days in the control and LP-s activated samples respectively (Figure 3). From the above trend we can see that the LP-s is effective to control the growth of microorganisms up to some time in the entire activated sample, especially acid forming bacteria. Since the acidity increased after some time, we can predict that the LP-s has bacteriostatic action on the acid producing bacteria at the initial phase. Likewise, though the result showed that though the acidity in both cases increased with time, the speed of increase in acidity for LP-s activated sample was lesser than the control sample. Similar trend was found by Elein et al., (1999) and Asaah et al., (2007).

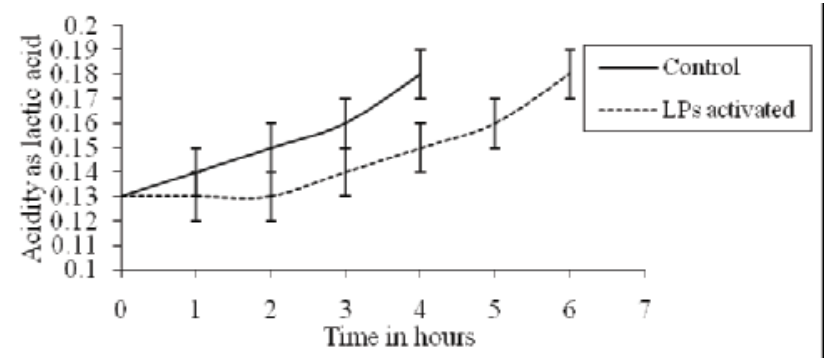

Figure 1.Acidity development with time at $35 \pm 2^{\circ} \mathrm{C}$

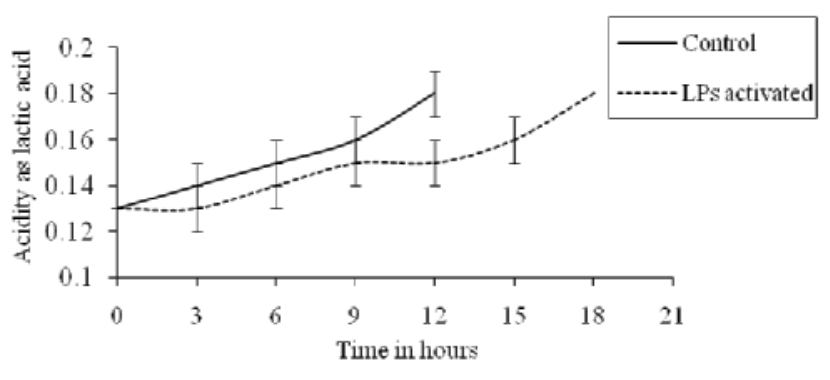

Figure 2.Acidity development with time at $25 \pm 3^{\circ} \mathrm{C}$

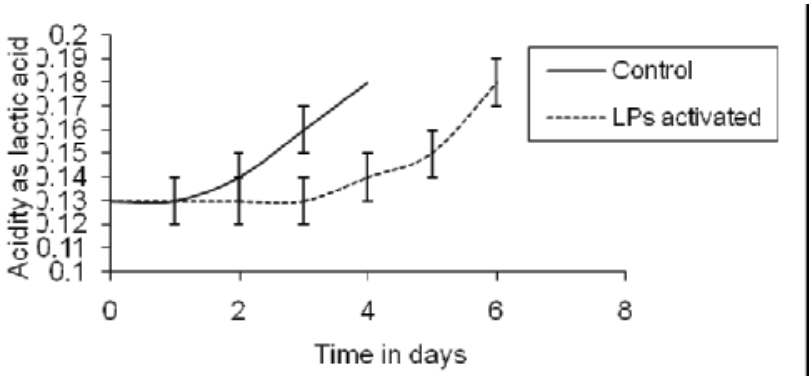

Figure 3.Acidity development with time at refrigeration $\left(5 \pm 2^{\circ} \mathrm{C}\right)$

The extension in shelf-life (ESL) at $(35 \pm 2)^{\circ} \mathrm{C}$ was only 2 hrs and there was no significant difference between the shelf-life of the control sample and LP-s activated raw milk sample at this condition. The low ESL ( $2 \mathrm{hrs}$ ) of LP-s activated milk might be due to the high initial microbial load. Valdez et al., (1988) found natural LP-s was inhibitory against microorganisms up to 8 hours in sample of bovine milk stored at $30^{\circ} \mathrm{C}$. Similarly Masud et al., (2004) found a shelf-life of 6 
Table 1.Effect of LP-s activation on the shelf-life of raw cow milk

\begin{tabular}{lccc}
\hline Storage temperature & \multicolumn{2}{c}{ Shelf-life } & Extension in shelf-life (ESL) \\
\cline { 2 - 3 } & LP-s activated & Control & \\
\hline At $(35 \pm 2)^{\circ} \mathrm{C}$ & $6 \pm 2^{\mathrm{a}}$ hours & $4 \pm 2^{\mathrm{a}}$ hours & $2 \pm 0$ hours \\
Room temperature $\left(25 \pm 3^{\circ} \mathrm{C}\right)$ & $18 \pm 0^{\mathrm{a}}$ hours & $12 \pm 3^{\mathrm{b}}$ hours & $6 \pm 3$ hours \\
Refrigerated condition $\left(5 \pm 2^{\circ} \mathrm{C}\right)$ & $6 \pm 1^{\mathrm{a}}$ days & $4 \pm 0^{\mathrm{b}}$ days & $2 \pm 2$ days \\
\hline
\end{tabular}

\section{Note: Values are the mean \pm Standard deviation and Superscript ${ }^{a b}=$ figures bearing different letters in thesame row indicatessignificant $(\mathbf{p}<0.05)$ difference.}

hours for control buffalo milk and 8 hours for LP-s activated sample kept at $35^{\circ} \mathrm{C}$. Marks et al., (2001) obtained a KQ of 75 hrs in LP-s activated pasteurized milk inoculated with $2.5 \mathrm{log}$ $\mathrm{cfu} / \mathrm{ml}$ Staphylococcus aureus at the same temperature. Hence it can be said that at higher temperature with high microbial load, the effect of LP-s is low.According to FAO/WHO, (2005) the shelf-life of hygienic raw milk is increased by 4-7 hours at $(31-35)^{\circ} \mathrm{C}$ by the activation of LP-s and the efficacy of the LP-s persists for a limited period of time, which decreases as the ambient temperature increases. Thus, good hygienic practices in milk production are critical to the efficacy of the LP-s and to the microbiological quality of the milk.

The average shelf-life for control and LP-s activated samples kept at $\left(25 \pm 3^{\circ} \mathrm{C}\right)$ was found to be $12 \pm 3 \& 18 \pm 0 \mathrm{hrs}$ respectively. The ESL was found to be $6 \mathrm{hrs}$ on average. On analysis of variance, it was found that there was significant difference $(p<0.05)$ between the shelf-life of the control and LP-s activated samples. The ESL is greater (by $1 \mathrm{hr}$ ) than that obtained by Asaah et al., (2007). According to FAO/ WHO, (2005) the shelf-life of collected hygienically extends for 11-12 hours for LP-s activated raw milk stored at $25^{\circ} \mathrm{C}$. Dionysius et al., (1992) obtained a shelf-life of $18 \mathrm{hrs}$ at $20^{\circ} \mathrm{C}$ with the activation of LP-s system (with $15 \& 10 \mathrm{mg} / \mathrm{L} \mathrm{SCN}$ and hydrogen peroxide) and $3 \mathrm{hrs}$ for the control sample. Thus it was concluded that the LP-s works effectively against the mesophilic bacteria and extends the shelf-life considerably at normal room temperature $\left(25 \pm 3^{\circ} \mathrm{C}\right)$, in spite of high microbial load.

Similarly at refrigerator temperature $\left(5 \pm 2^{\circ} \mathrm{C}\right)$, the shelf-life of control and LP-s activated samples were found to be $4 \pm 0$ days and $6 \pm 1$ days respectively. The average ESL for the LP-s activated sample was found to be 2 days. At similar conditions $\left(6-8^{\circ} \mathrm{C}\right)$, Asaah et al., (2007) obtained shelf-life of 2.25 and 7 days for control and LP-s activated samples. Similarly, Haddadin et al., (1996) obtained a shelf life of 6 days at refrigerated temperature by the activation of lactoperoxidase in raw milk, while Saha et al., (2003) obtained an ESL of one day by activating lactoperoxidase only by the addition of hydrogen peroxide.According to $\mathrm{FAO} / \mathrm{WHO},(2005)$, at $4^{\circ} \mathrm{C}$, the LP-s can extend the shelf-life of raw milk upto 5-6 days. The analysis of variance showed that there was significant difference $(p<0.05)$ between the life of the two samples kept under refrigeration. This result confirms the statement of FAO/ WHO, 2005; "the LP-s can delay growth of psychrotrophic milk bacteria and thus delay milk spoilage for several days compared to what can be achieved with refrigeration alone".

\section{Conclusion}

Thus, from the present study it can be concluded that the shelf-life of raw cow milk can be increased significantly by the activation of lactoperoxidase system at room temperature $\left(25 \pm 3^{\circ} \mathrm{C}\right)$ and at refrigeration temperature $\left(5 \pm 2^{\circ} \mathrm{C}\right)$. However increase in shelf-life of raw cow milk held at high temperature $\left(35 \pm 2^{\circ} \mathrm{C}\right)$ was not significant with the control samples.This shows that the LP-s is ineffective at higher temperatures coupled with high microbial load. The use of the LP-s provides a reliable and economical alternative for preserving raw milk, particularly in small-scale dairy enterprises when coupled with adequate hygiene and sanitation.

\section{References}

Acharya A. (2010). Ultra high temperature technology for processing of long life milk a prospect in Nepal. Paper submitted for the partial fulfillment of undergraduate degree in industrial engineering, Institute of Engineering, Tribhuvan University, Thapathali, Kathmandu, Nepal.

Asaah N. O., Fonteh F., Kamga P., Pamela K., Mendi S. and Imele H.(2007). Activation of the Lactoperoxidase System as a Method of Preserving Raw Milk in Areas without Cooling Facilities. African Journal of Food Agriculture Nutrition and Development. Vol. 7:2. 2007. Available at: http://www.bioline.org.br/pdf?nd07015 [Accessed 27 Aug, 2010].

Bjorck L., Rosen V., Marshall V., and Reiter B. (1975). Antimicrobial Activity of the lactoperoxidase System in Milk against Pseudomonal and other Gram-negative Bacteria. Available at: https://www.ncbi.nlm.nih.gov/ pmc/articles/PMC187155/pdf/applmicro00026-0053.pdf [Accessed 28 Aug, 2010]

Bylund G. (1995). Dairy Processing Handbook, Tetrapak, Sweden.

CAC, (1991b).Guidelines for the preservation of raw milk by use of the lactoperoxidase system (CAC/ GL13/1991). Available at: http://www.codexalimentarius. 
net/download/standards/29/CXG_013e.pdf[Accessed 12 Dec, 2009].

CBS (2008). Statistical Year Book of Nepal 2008, Central Bureau of Statistics, Government of Nepal.

De S. (2008). Outlines of Dairy Technology. Oxford University Press, 2008.

Dionysius D.A., Grieve P.A. and Vos A.C. (1992). Studies on the lactoperoxidase system: reaction kinetics and antibacterial activity using two methods for hydrogen peroxide generation. Journal of Applied Microbiology, vol 72 (2): 146-153, Feb 1992.

Eckles C. H., Combs B. W., and Macy H. (1973). Milk and milk products, $4^{\text {th }}$ edn. Tata McGraw-Hill Publishing Company Limited, New Delhi, India.

Elein S. G., Ghany E. I. And Liala M.M. 1999. Bacterial Effect of Some Pretreatments of Raw Milk on Its Keeping Quality in Egypt. J. Dairy Sci. 27(1): 59-70. In Preservation Of Raw Buffalo's Milk By The Activation Of Lactoperoxidase System And Its Effect On Yogurt Preparation.(Tariq Masud, Sadia Khalid, S. MaqsoodAnd Ahmed Bilal) In http://www.aginternetwork. net/whalecomonlinelibrary.wiley.com/whalecom0/ doi/10.1111/j.1745-4549.2008.00337.x/full [Accessed28 Aug 2010].

FAO/WHO. (2005). Benefits and potential risks of the lactoperoxidase system on raw milk preservation. Report of FAO/WHO technical meeting, FAO Headquarters, Rome, Italy, 28 November - 2 December, 2005.

Fernández O., Marrero E. and Capdevila J. Z. (2005). Techincal note on "Safety Consideration on Lactoperoxidasee System use for Milk Preservation". Rev. Salud Amin. 27 :3 2005 pp 186-189. Available at: http://www.censa. edu.cu/index2.php? option $=$ com docman\&task $=$ doc view\&gid $=332 \&$ Itemid $=105$ [Accessed 26 Aug 2010].

Frazier W. C. and Westhoff D. C. (1995). Food microbiology, $4^{\text {th }}$ edition, Tata McGraw-Hill Publishing Company Limited, New Delhi, India.
Haddadin M.S., Ibrahim S.A. and Robinson R.K. (1996). Preservation of Raw Milk By the Activation of Natural Lactoperoxidase Systems. Food Control,7(3): 149-152. 1996. Elsevier Science Ltd. UK.

Jacqueline M. O. (2006). The impact of the combined lactoperoxidase and pasteurization treatment on the safety of goat milk and cottage cheese. A dissertation Submitted in partial fulfillment of the requirements for the degree Masters in Institutional Agriculture (Food production and Processing) University of Pretoria, Pretoria, Republic of South Africa. November 2006.

Mark N. E., Grandsion A.S. and Lewis M.J., (2001). Challenge testing of the lactoperoxidase system in pasteurized milk. Journal of Applied Microbiology, 91:735-741.

Masud T., Khalid S., Maqsood S. and Bilal A. (2004). Preservation of Raw Buffalo's Milk by the Activation of Lactoperoxidase System and its Effect on Yogurt Preparation. Available at: http://onlinelibrary.wiley.com/ doi/10.1111/j.1745-4549.2008.00337.x/pdf [Accessed 15 Aug 2010].

NDDD (2001). Nepal Dairy Development Board. Laboratory Handbook for Dairy Industry. 2001

Saha B. K., Ali M.Y., Chakraborty M., Islam Z. and Hira A. K. (2003) Study on the Preservation of Raw Milk with Hydrogen Peroxide for Rural Dairy Farmers Pakistan Journal of Nutrition 2 (1): 36-42.

Valdez G. E, Bibi W. and Bachmann M.R. (1988) Antibacterial effect of the LP system on the activity of thermophilic starter culture. Milchwissenschaft,43:350-352. In: Preservation of raw milk by activation of the natural lactoperoxidase systems. (M.S. Haddadin, S.A. Ibrahim and R.K. Robinson). Food Control. 7 (3): 149-152. 1996. Elsevier Science Ltd. UK.

Walstra P., Woulters Jan T. M., and Geurts Tom J. (2006). Dairy Science and Technology, $2^{\text {nd }}$ end. CRC Press Taylor and Franscis Group, US.

Younan M. (2010). Milk Hygiene and Udder Health. Available at: www.camelgate.com/pdf/milk_hygiene_and_udder health.pdf [Accessed 15 Aug 2010]. 